\title{
Sequential Applications of Synthetic Auxins and Glufosinate for Escaped Palmer Amaranth Control
}

\author{
Frances B. Browne ${ }^{1}$, Xiao Li ${ }^{1, * \mathbb{D}}$, Katilyn J. Price ${ }^{1}$, Ryan Langemeier ${ }^{1}$, \\ Alvaro Sanz-Saez de Jauregui ${ }^{1}$, J. Scott McElroy ${ }^{1}$, Yucheng Feng ${ }^{1}$ and Andrew Price ${ }^{2}$ \\ 1 Department of Crop, Soil and Environmental Sciences, Auburn University, Auburn, AL 36849, USA; \\ frances.browne@corteva.com (F.B.B.); kjp0030@auburn.edu (K.J.P.); rd10025@auburn.edu (R.L.); \\ azs0223@auburn.edu (A.S.-S.d.J.); jsm0010@auburn.edu (J.S.M.); fengyuc@auburn.edu (Y.F.) \\ 2 USDA-ARS Nation Soil Dynamics Laboratory, Auburn, AL 36830, USA; andrew.price@usda.gov \\ * Correspondence: steveli@auburn.edu; Tel.: +1-334-844-3804
}

Received: 7 September 2020; Accepted: 16 September 2020; Published: 19 September 2020

\begin{abstract}
Field and greenhouse studies were conducted to investigate the influence of sequence and timing of synthetic auxins and glufosinate on large Palmer amaranth (Amaranthus palmeri) control. Field studies were performed in Henry County, AL where treatments were applied to Palmer amaranth with average heights of 37 and $59 \mathrm{~cm}$ in 2018 and 2019, respectively. Sequential applications of 2,4-D/dicamba + glyphosate followed by (fb) glufosinate at labeled rates 3 or 7 days after initial treatment (DAIT) were used in addition to the reverse sequence with a 7-day interval. Time intervals of 3 or 7 days between applications did not influence Palmer amaranth control. Palmer amaranth was controlled $100 \%$ by dicamba + glyphosate fb glufosinate and 2,4-D + glufosinate fb glufosinate 7 DAIT in 2018. However, herbicide performance was reduced due to delayed application and taller plants in 2019 with up to $23 \%$ less visual injury. To further investigate Palmer amaranth response to dicamba and glufosinate applied sequentially, a greenhouse study was conducted in 2019 where physiological measurements were recorded over a 35-day period. Treatments were applied to Palmer amaranth averaging $38 \mathrm{~cm}$ tall and included dicamba + glyphosate fb glufosinate 7 DAIT, the reverse sequence, and a single application of dicamba + glufosinate + glyphosate. Glufosinate severely inhibited mid-day photosynthesis compared to dicamba with up to $90 \%$ reductions in $\mathrm{CO}_{2}$ assimilation 1 DAIT. In general, Palmer amaranth respiration and stomatal conductance were not affected by herbicides in this study. Applications of dicamba + glyphosate fb glufosinate 7 DAIT was the only treatment hindered Palmer amaranth regrowth with 52\% reduction in leaf biomass compared to nontreated control. These data suggest Palmer amaranth infested fields are more likely to be rescued with sequential applications of synthetic auxins and glufosinate, but consistent control of large Palmer is not probable.
\end{abstract}

Keywords: biomass; visual injury; photosynthesis; regrowth; $\mathrm{CO}_{2}$ assimilation; rescue treatment; height

\section{Introduction}

Palmer amaranth (Amaranthus palmeri S. Wats) is a weed that remains at the center of row crop management concerns in the USA due to rapid growth and constant evolution of herbicide resistance. The dioecious growth habit and high fecundity associated with this weed are major factors responsible for the rate at which herbicide resistant populations have evolved and spread [1-3]. Even low Palmer amaranth density can lead to yield loss, reduced harvest efficiency, and accumulation of seeds in the soil [4-6]. Large plant height at maturity, high water use efficiency, drought tolerance mechanisms, and a $\mathrm{C} 4$ photosynthetic pathway provide Palmer amaranth with a competitive advantage over 
cotton (Gossypium hirsutum L.) and soybeans (Glycine max L.) which are C3 plants [3,7-9]. Palmer amaranth density can significantly impact cotton and soybean canopy width and further impede crop competitiveness [6,10]. Klingaman and Oliver [10] reported soybean width reductions of $54 \%$ twelve weeks after emergence (WAE) with 10 Palmer amaranth per $1 \mathrm{~m}$ of crop row. Similarly, Morgan et al. [6] reported $45 \%$ cotton canopy volume reductions 10 WAE with 1 to 10 Palmer amaranth per $9.1 \mathrm{~m}$ of row. Significant yield losses of $92 \%$ and $78 \%$ have been reported for cotton and soybean, respectively, when grown with Palmer amaranth at densities of eight plants per $1 \mathrm{~m}$ of row [11,12]. Norsworthy et al. [13] reported, 20,000 Palmer amaranth seed spread in a $1 \mathrm{~m}^{2}$ area resulted in complete cotton crop failure due to high infestations three years later. A single Palmer amaranth female is capable of producing up to 1 million seeds, indicating one escape could significantly impact cropping systems in a relatively short period of time $[13,14]$. These data support the adoption of a zero-tolerance threshold and aggressive measures are needed to prevent Palmer amaranth plants from reaching reproductive maturity.

Increasing infestations of herbicide-resistant Palmer amaranth have driven producers to seek alternative means for control. Recently commercialized transgenic cotton and soybean varieties in the USA with tolerance to 2,4-D or dicamba and glufosinate can provide new tools for Palmer amaranth control during the growing season. To date, glufosinate resistance has not been confirmed in Palmer amaranth populations, thus this herbicide remains a viable herbicide option for control when applied according to label recommendations $[15,16]$. Palmer amaranth resistance to auxin herbicides has been reported [15,17]; however, populations appear to be isolated at this point and research suggests both 2,4-D and dicamba remain effective options for control of most of row crop growers in the USA [18-20].

If producers do not use preemergence herbicides or adequate rainfall does not occur soon after application for activation in dryland systems, escapes will need to be controlled through postemergence (POST) herbicide applications. POST control of Palmer amaranth is time sensitive, adverse weather conditions, unforeseen equipment failure, or inadequate coverage due to poor nozzle selection can allow plants to quickly exceed optimal heights for control. Under such circumstances, producers often seek out rescue herbicide programs to control large escapes and prevent crop loss [19,21-23]. Combinations of glufosinate and synthetic auxins have been shown to be more effective on control of larger weeds than when applied alone [19,21,24-26]. Merchant et al. [24] observed up to $22 \%, 17 \%$, and $11 \%$ greater Palmer amaranth control $20 \mathrm{~d}$ after application when glufosinate at $431 \mathrm{~g}$ ai ha ${ }^{-1}$ was tank mixed with 2,4-DB, 2,4-D, or dicamba than when these three herbicides applied alone at 1120, 1064, and $1120 \mathrm{~g}_{\text {ai ha }}{ }^{-1}$, respectively. Additionally, sequential applications of postemergence herbicides are more likely to control Palmer amaranth than one-time applications [27]. Coetzer et al. [27] reported $80 \%$ and $55 \%$ Palmer amaranth population size reductions following sequential applications of glufosinate at 410 and $293 \mathrm{~g}$ ai ha $^{-1}$, respectively, whereas single applications did not reduce population size relative to the nontreated control.

Current dicamba labels do not permit tank mixtures with glufosinate due to volatility concerns [28-30]. Therefore, sequential applications will be required when both herbicides are utilized in a weed management program. New formulation of 2,4-D choline (Enlist One ${ }^{\circledR}$, Dow AgroSciences, Indianapolis, IN 46268, USA) allows tank mixtures with glufosinate which could provide more flexibility in POST herbicide treatments [30]. Control of Palmer amaranth is likely to be influenced by the combination and sequence of synthetic auxins and glufosinate in addition to the time intervals between applications, which is not well understood at this moment. Therefore, the objective of this study was to evaluate sequential applications of synthetic auxins and glufosinate at different sequences and time intervals for Palmer amaranth control in a rescue scenario. We hypothesize sequential applications of auxin herbicides and glufosinate will result in better Palmer amaranth control than single application, and auxin herbicides applied before or after glufosinate provides better Palmer amaranth control than glufosinate alone applied twice. 


\section{Materials and Methods}

\subsection{Field Studies}

Two non-crop studies were conducted at the Wiregrass Research and Extension Center in Henry County, AL ( $\left.31^{\circ} 21^{\prime} 17.1^{\prime \prime} \mathrm{N} 85^{\circ} 19^{\prime} 35.3^{\prime \prime} \mathrm{W}\right)$ during summers of 2018 and 2019 in irrigated field with high Palmer amaranth pressure. The site included natural and augmented Palmer amaranth populations planted at 500 seeds $\mathrm{m}^{-2}$ on June 6 and May 10 in 2018 and 2019, respectively. Prior to seeding, the study area was disked thoroughly to remove existing weeds, then field cultivated to ensure smooth soil surface. An artificial population combined with existing population was established by spreading Palmer amaranth seeds sourced from peanut and cotton fields in Alabama with known glyphosate and ALS-inhibitor resistance. Mature female seed heads were collected in late September before crop harvest and cleaned by hand on Auburn University campus for Palmer seeds. Other weed species presented in the non-crop plots included morning glory (Ipomoea spp.), sicklepod (Senna obtusifolia), Florida pusley (Richardia scabra), Florida beggarweed (Desmodium tortuosum), and southern crabgrass (Digitaria ciliaris). The experimental design was a randomized complete block with four replications. Plot size was $3.3 \mathrm{~m}$ long by $3.3 \mathrm{~m}$ wide. Herbicide treatments and rates can be found in Table 1 and consisted of combinations of 2,4-D choline (Enlist One ${ }^{\circledR}$; Dow AgroSciences LLC, Indianapolis, IN 46268 , USA) or diglycolamine salt of dicamba with a built in pH buffer (Xtendimax ${ }^{\circledR}$ with Vaporgrip ${ }^{\circledR}$; Monsanto Co. St. Louis, MO 63167, USA), glufosinate (Liberty ${ }^{\circledR} 280$ SL; BASF Corporation, Research Triangle Park, NC 27709, USA), and glyphosate (Roundup PowerMax ${ }^{\circledR}$; Monsanto Co. St. Louis, MO 63167, USA) at 1063, 559, 594, and $1540 \mathrm{~g}$ ai ha ${ }^{-1}$ (Table 1$)$.

Table 1. Herbicide treatments used in field study $\mathrm{A}, \mathrm{B}, \mathrm{C}$.

\begin{tabular}{cccc}
\hline$\#$ & POST-1 & POST-2 & $\begin{array}{c}\text { POST-2 Timing } \\
\text { (DAIT) } \mathbf{D}, \mathrm{E}\end{array}$ \\
\hline 1 & 2,4-D + glyphosate & glufosinate & 3 \\
2 & 2,4-D + glyphosate & glufosinate & 7 \\
3 & 2,4-D + glufosinate & glufosinate & 7 \\
4 & 2,4-D + glufosinate & 2,4-D + glufosinate & 7 \\
5 & 2,4-D + glufosinate & 2,4-D + glyphosate & 7 \\
6 & Glufosinate & 2,4-D + glyphosate & 7 \\
7 & Dicamba + glyphosate & glufosinate & 3 \\
8 & Dicamba + glyphosate & glufosinate & 7 \\
9 & Dicamba + glyphosate & dicamba + glyphosate & 7 \\
10 & Glufosinate & dicamba + glyphosate & 7 \\
11 & Glufosinate & glufosinate & 7 \\
\hline
\end{tabular}

A 2,4-D, dicamba, glufosinate and glyphosate were applied at 1066, 559, 594, and $1543 \mathrm{~g}$ ai ha ${ }^{-1}$. ${ }^{\mathrm{B}}$ All herbicide treatments were tank mixed with a water conditioning agent/nonionic surfactant blend at $1 \% v / v$ (Class Act ${ }^{\circledR}$ Ridion $^{\circledR}$, Winfield Solutions, LLC, St. Paul, MN 55164, USA). ${ }^{C}$ Dicamba treatments were tank mixed with a drift reduction agent at $0.5 \%$ v/v (Intact, Precision Laboratories, LLC, Waukegan, IL 60085, USA) as required by federal label. D Abbreviation: DAIT, days after initial treatment. ${ }^{\mathrm{E}} \mathrm{S}$-metolachlor was applied once 7 days after initial herbicide application at $1469 \mathrm{~g}$ ai ha ${ }^{-1}$ on all treated plots to limit Palmer amaranth seed germination later in the study.

Glyphosate was used in tank mixture with dicamba and 2,4-D choline to provide control of annual grass weeds and broadleaf weeds that are not resistant to glyphosate, which is a common practice for row crop farmers in the southeast US. It does not provide any control of resistant Palmer amaranth in this field. Initial herbicide applications were performed on 6 July and 12 June in 2018. A blanket application of $S$-metolachlor (Dual Magnum ${ }^{\circledR}$; Syngenta Crop Protection, LLC, Greensboro, NC 67419, USA) was applied once 7 days after initial herbicide application at $1469 \mathrm{~g}$ ai ha ${ }^{-1}$ on all treated plots to limit Palmer amaranth seed germination later in the study, thus confounding ratings and data collection. Herbicides were applied to Palmer amaranth with average height of 37 and 59 $\mathrm{cm}$ tall in 2018 and 2019, respectively. All herbicides were applied with a $\mathrm{CO}_{2}$-pressurized backpack 
sprayer equipped with four TeeJet nozzles (TeeJet Technologies, Wheaton, IL 60187, USA) delivering $187 \mathrm{~L} \mathrm{ha}^{-1}$. Turbo TeeJet induction flat spray tips (TTI 110025, TeeJet Technologies, Wheaton, IL 60187, USA) producing ultra-coarse droplets were used for treatments that included synthetic auxins to reduce spray drift as label required, and Turbo TeeJet wide angle flat fan spray tips (TT 110025, TeeJet Technologies, Wheaton, IL 60187, USA) producing medium size droplets were used for glufosinate applications to increase spray coverage.

Palmer amaranth injury was visually estimated at 14 and 28 DAIT on a scale of 0 (no injury) to 100 (complete mortality). At 35 DAIT, ten Palmer amaranth heights were recorded randomly in each plot by measuring living individuals from the ground to the top of the plant. Palmer amaranth in each plot were cut at ground level 35 DAIT and immediately weighted to determine fresh biomass. Plants were only harvested from the middle area $(2.4 \times 2.4 \mathrm{~m})$ in each plot to ensure adequate herbicide coverage was received.

Data were subjected to a mixed model analysis of variance through PROC GLIMMIX in SAS 9.4 (Statistical Analysis Systems ${ }^{\circledR}$, version 9.4; SAS Institute Inc., Cary, NC 27513, USA). Treatment and year were considered fixed effects, while block was a random effect and all interactions were examined. If treatment by year interactions were observed, data was analyzed separately to show individual effects for each year. Means comparisons were generated using Tukey's Honest Significant (HSD) different test with $p=0.05$.

\subsection{Greenhouse Study}

In order to better understand Palmer amaranth physiological response to synthetic auxins and glufosinate, an experiment was conducted in a greenhouse with natural daylight at Auburn University in Auburn, AL during June of 2019. Temperatures ranged between 20 and $31^{\circ} \mathrm{C}$ throughout the course of the study. Glyphosate and ALS-inhibitor resistant Palmer amaranth seed collected from Headland, AL were planted in $4 \mathrm{~L}$ pots filled with commercial potting soil (Miracle-Gro ${ }^{\circledR}$ Moisture Control ${ }^{\circledR}$ Potting Mix, The Scotts Company LLC, Marysville, OH 43040, USA). Plants were thinned to two plants per pot and grown until reaching 30 to $45 \mathrm{~cm}$ in height with irrigation and fertilizer applied as needed. One leaf on each plant was tagged with plastic string at the petiole, representing a young fully developed leaf (3-4 node position from the tip), to ensure the same leaf was measured throughout the study.

The experimental design was a randomized complete block with three replications in two separate runs. In addition to a nontreated control, treatments included a tank mixture of dicamba + glufosinate + glyphosate, dicamba + glyphosate fb glufosinate 7 DAIT, and glufosinate fb dicamba + glyphosate 7 DAIT. Reduced herbicide rates relative to the field study were chosen to allow Palmer amaranth survival and enable for physiological measurements up to $35 \mathrm{~d}$ after initial treatments. Dicamba, glufosinate, and glyphosate were applied at 186, 198, and $514 \mathrm{~g}$ ai ha ${ }^{-1}$. Herbicides were applied using a $\mathrm{CO}_{2}$-pressurized backpack sprayer equipped with two flat fan 110,025 nozzles delivering $187 \mathrm{~L} \mathrm{ha}^{-1}$. Dicamba was applied with Turbo TeeJet induction flat fan nozzles (TTI110025, TeeJet Technologies, Wheaton, IL 60187, USA) and glufosinate with Turbo TeeJet wide angle flat fan nozzles (TT110025, TeeJet Technologies, Wheaton, IL 60187, USA).

Physiological measurements were recorded at 1,3, 6, 8, 11, 13, and 35 DAIT. Measurements included mid-day photosynthesis, leaf stomatal conductance, and respiration, collected with a LI-6400XT (LI-COR Biosciences, Lincoln, NE 68504, USA). Before each midday photosynthesis measurements, light intensity in the greenhouse was recorded by a photosynthetic photon flux density meter (LI-190; LICOR Biosciences, Lincoln, NE, USA), temperature was monitored by an onsite weather station, and relative humidity was maintained between $60 \%$ and $70 \%$. Conditions in the leaf cuvette were then set to match ambient environmental conditions, with the $\left[\mathrm{CO}_{2}\right]$ in the cuvette set to match ambient [CO2] ( $\sim 10 \mathrm{ppm})$. The methodology for respiration measurements was the same but the light intensity was set to $0 \mu \mathrm{mol} \mathrm{mol}{ }^{-1}$. Photosystem II (PSII) quantum yield was recorded with a portable fluorometer (FluorPen FP 100, Photon Systems Instruments, Albuquerque, NM, USA 87106). Photosynthesis and 
stomatal conductance measurements were recorded at solar noon (11:00-13:00) while respiration and PSII quantum yield measurements were collected from dark-adapted plants two hours after sunset. At the end of physiological measurements, all Palmer amaranth leaves were removed at the petiole base 14 DAIT, fresh weight was recorded, then leaves were processed through a LI-3100C area meter (LI-COR Biosciences, Lincoln, NE 68504, USA) to determine total leaf area. Palmer amaranth bare stalks were allowed to resume growth until 35 DAIT when photosynthesis, respiration and fluorescence measurements were repeated as indicated above, and leaves were removed at the petiole base once more and weighted.

Each physiological measurement was averaged across the two tagged leaves per pot and data was subjected to a mixed model analysis of variance through PROC GLIMMIX in SAS ${ }^{\circledR}$ 9.4 (Statistical Analysis Systems ${ }^{\circledR}$, version 9.4; SAS Institute Inc., Cary, NC 27513, USA) with treatment considered as a fixed effect. Data were pooled across experiment repetitions which was considered a random variable. Scatter plots were generated in Sigmaplot 13.0 (Systat Software, San Jose, CA 95131, USA) and means comparisons were generated using Tukey's HSD test with $p=0.05$.

\section{Results}

\subsection{Field Study: 2,4-D Choline-Based Programs}

A year by treatment interaction was observed for Palmer amaranth control 14 DAIT, height, and biomass for 2,4-D based programs. No interaction was observed for Palmer amaranth control 28 DAIT; therefore, data were combined across years for 28 DAIT (Tables 2 and 3).

Table 2. Palmer amaranth control as affected by sequential applications of 2,4-D and glufosinate in 2018 and 2019 field studies.

\begin{tabular}{|c|c|c|c|c|c|c|c|c|}
\hline \multicolumn{3}{|c|}{ Treatments ${ }^{A, B}$} & \multicolumn{6}{|c|}{ Control ${ }^{\mathrm{D}, \mathrm{E}}(\%)$} \\
\hline \multirow{2}{*}{ POST-1 } & \multirow{2}{*}{ POST-2 } & \multirow{2}{*}{ POST-2 Timing (DAIT) ${ }^{\mathrm{C}}$} & \multicolumn{4}{|c|}{14 DAIT $^{\text {F }}$} & \multirow{2}{*}{\multicolumn{2}{|c|}{$\begin{array}{c}28 \text { DAIT G }^{\text {G }} \\
2018-2019\end{array}$}} \\
\hline & & & \multicolumn{2}{|c|}{2018} & \multicolumn{2}{|c|}{2019} & & \\
\hline 2,4-D + glyphosate & glufosinate & 3 & 94 & $a b$ & 94 & $\mathrm{a}$ & 93 & a \\
\hline 2,4-D + glyphosate & glufosinate & 7 & 97 & $\mathrm{a}$ & 74 & $\mathrm{~b}$ & 86 & $a b$ \\
\hline $2,4-\mathrm{D}+$ glufosinate & glufosinate & 7 & 100 & a & 95 & $\mathrm{a}$ & 84 & $\mathrm{ab}$ \\
\hline $2,4-\mathrm{D}+$ glufosinate & 2,4-D + glufosinate & 7 & 96 & $\mathrm{a}$ & 96 & $\mathrm{a}$ & 93 & $\mathrm{a}$ \\
\hline $2,4-\mathrm{D}+$ glufosinate & $2,4-\mathrm{D}+$ glyphosate & 7 & 84 & $\mathrm{bc}$ & 93 & $\mathrm{a}$ & 80 & $\mathrm{abc}$ \\
\hline Glufosinate & $2,4-\mathrm{D}+$ glyphosate & 7 & 74 & $c$ & 96 & $\mathrm{a}$ & 76 & $\mathrm{bc}$ \\
\hline Glufosinate & glufosinate & 7 & 91 & $a b$ & 97 & $\mathrm{a}$ & 68 & $\mathrm{c}$ \\
\hline
\end{tabular}

A 2,4-D, glufosinate and glyphosate were applied at 1066, 594, and $1543 \mathrm{~g}$ ai ha ${ }^{-1}$. ${ }^{\mathrm{B}}$ All treatments included a water conditioning agent/nonionic surfactant blend at $1 \% v / v$ (Class Act ${ }^{\circledR}$ Ridion $^{\circledR}$, Winfield Solutions, LLC, St. Paul, MN 55164, USA). ${ }^{C}$ Abbreviation: DAIT, days after initial treatment. D Visual injury estimated on a scale of $0 \%$ (no injury) to $100 \%$ (complete mortality). ${ }^{\mathrm{E}}$ Means within a column followed by the same letter do not differ significantly at $p=0.05$ based on Tukey's HSD. ${ }^{\mathrm{F}}$ A treatment by year interaction was observed for Palmer amaranth control 14 DAIT at $p=0.05$; therefore, data were analyzed and presented separately for each year. ${ }^{\mathrm{G}}$ No treatment by year interaction was observed for Palmer amaranth control 28 DAIT at $p=0.05$; therefore, data were combined across years to show treatment effects.

All 2,4-D choline and glufosinate based treatments provided greater than $90 \%$ Palmer amaranth control 14 DAIT in 2018 with exception of 2,4-D + glufosinate fb 2,4-D + glyphosate 7 DAIT and glufosinate fb 2,4-D + glyphosate 7 DAIT which provided 84 and 74\% control, respectively (Table 2). Although applications of 2,4-D + glyphosate fb glufosinate 7 DAIT provided 97\% control 14 DAIT in 2018, only 74\% control was observed in 2019 which was significantly lower than other treatments. All other 2,4-D choline and glufosinate based treatments provided greater than 90\% control 14 DAIT in 2019.

All 2,4-D and glufosinate combinations where 2,4-D was included in initial applications provided statistically similar control 28 DAIT, ranging from 80 to 93\%. In comparison, sequential applications of glufosinate or glufosinate fb 2,4-D + glyphosate resulted in significantly lower control 28 DAIT of $68 \%$ and $76 \%$, respectively. Time intervals of 3 and $7 \mathrm{~d}$ did not influence the level of control 
of 2,4-D + glyphosate fb glufosinate at 14 and 28 DAIT. Similar to this study, Merchant et al. [19] observed poor Palmer amaranth control at cotton layby (79\%) with sequential glufosinate applications at $471 \mathrm{~g}$ ai ha ${ }^{-1}$ spaced $15 \mathrm{~d}$ apart but reported at least $95 \%$ control when 2,4-D at $1120 \mathrm{~g}$ ai ha ${ }^{-1}$ was mixed with glufosinate at each application. Craigmyle et al. [25] also reported 19\% higher control of Amaranthus sp. 30 to $35 \mathrm{~cm}$ tall with sequential applications of 2,4-D + glufosinate at 1.12 and $0.45 \mathrm{~kg}$ ai ha ${ }^{-1}$, respectively, as opposed to glufosinate alone. Data from these studies suggested sequential applications of glufosinate alone or glufosinate applied before 2,4-D are not sufficient for controlling large Palmer amaranth. Greater Palmer amaranth control was achieved by either applying 2,4-D before glufosinate, or by applying both 2,4-D and glufosinate in a tank mixture fb either 2,4-D or glufosinate or combination of the two 3 or 7 days later.

Table 3. Palmer amaranth height and biomass as affected by sequential applications of 2,4-D and glufosinate in 2018 and 2019 field studies.

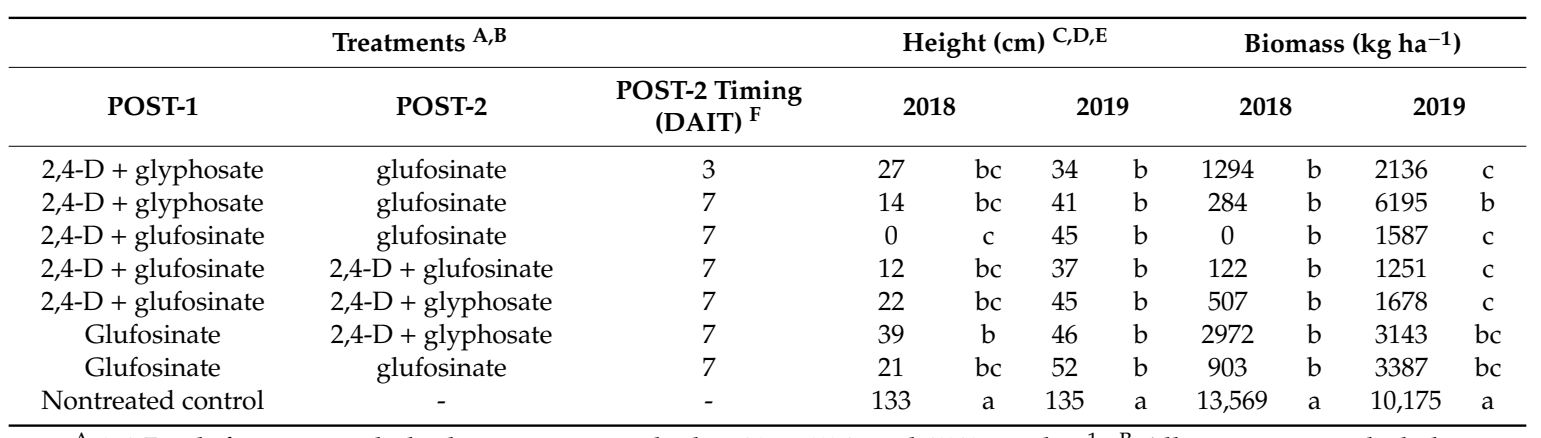

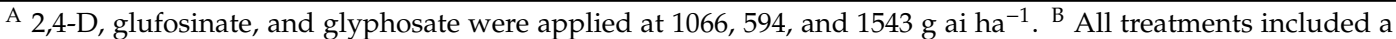
water conditioning agent/nonionic surfactant blend at $1 \% v / v\left(\right.$ Class Act ${ }^{\circledR}$ Ridion ${ }^{\circledR}$, Winfield Solutions, LLC, St. Paul, MN 55164, USA). C Palmer amaranth height and above-ground fresh biomass recorded 35 DAIT. ${ }^{D}$ Means within a column followed by the same letter do not differ significantly at $p=0.05$ based on Tukey's HSD. E A year by treatment interaction was observed for Palmer amaranth height and biomass 35 DAIT at $p=0.05$; therefore, data were analyzed and presented separately for each year. ${ }^{\mathrm{F}}$ Abbreviation: DAIT, days after initial treatment.

With exception of 2,4-D + glufosinate fb glufosinate 7 DAIT which resulted in $100 \%$ control in 2018, Palmer amaranth height was similar for all other treatments in 2018 and 2019 (Table 3). All treatments resulted in significantly reduced plant height and biomass relative to the nontreated control for 2018 and 2019. Herbicide treatments did not differ significantly in terms of Palmer amaranth biomass in 2018, which ranged from 0 to $2972 \mathrm{~kg} \mathrm{ha}^{-1}$ for treated plots. Treatments of 2,4-D + glufosinate $\mathrm{fb}$ glufosinate and 2,4-D + glufosinate $\mathrm{fb} 2,4-\mathrm{D}+$ glufosinate tank mixtures resulted in the greatest reductions of biomass and height in 2018 as compared to the nontreated control. Applications of 2,4-D + glyphosate fb glufosinate 3 DAIT and 2,4-D + glufosinate fb 2,4-D + glufosinate produced the lowest Palmer height and biomass, respectively, in 2019. Poor Palmer amaranth control in 2019 was observed in terms of biomass as all treatments resulted in $1250 \mathrm{~kg} \mathrm{ha}^{-1}$ or greater biomass, due to delayed application and larger size of Palmer at herbicide application.

\subsection{Field Study: Dicamba-Based Programs}

No treatment by year interaction was observed for Palmer amaranth control 14 DAIT. However, a treatment by year interaction was observed for control 28 DAIT, height, and biomass at $p=0.05$. Therefore, data was presented by year for those datasets. Glufosinate applied sequentially provided statistically similar control 14 DAIT as dicamba + glyphosate fb glufosinate 3 or 7 DAIT and dicamba + glyphosate fb dicamba + glyphosate 7 DAIT (Table 4). 
Table 4. Palmer amaranth control as affected by sequential applications of dicamba and glufosinate in 2018 and 2019 field studies.

\begin{tabular}{|c|c|c|c|c|c|c|c|c|}
\hline \multicolumn{3}{|c|}{ Treatments ${ }^{A}$} & \multicolumn{6}{|c|}{ Control (\%) ${ }^{\mathrm{B}, \mathrm{C}}$} \\
\hline \multirow{2}{*}{ POST-1 } & \multirow{2}{*}{ POST-2 } & \multirow{2}{*}{$\begin{array}{l}\text { POST-2 Timing } \\
\text { (DAIT) }^{\mathrm{F}}\end{array}$} & & $T^{D}$ & \multicolumn{4}{|c|}{28 DAIT $^{\mathrm{E}}$} \\
\hline & & & \multicolumn{2}{|c|}{ 2018-2019 } & \multicolumn{2}{|c|}{2018} & \multicolumn{2}{|c|}{2019} \\
\hline Dicamba + glyphosate & glufosinate & 3 & 93 & $\mathrm{a}$ & 85 & $\mathrm{ab}$ & 89 & a \\
\hline Dicamba + glyphosate & glufosinate & 7 & 87 & $a b$ & 100 & a & 79 & $\mathrm{ab}$ \\
\hline Dicamba + glyphosate & dicamba + glyphosate & 7 & 79 & $a b$ & 85 & $a b$ & 91 & $\mathrm{a}$ \\
\hline Glufosinate & dicamba + glyphosate & 7 & 77 & $\mathrm{~b}$ & 70 & $\mathrm{~b}$ & 76 & $a b$ \\
\hline Glufosinate & glufosinate & 7 & 94 & $\mathrm{a}$ & 78 & $\mathrm{~b}$ & 57 & $\mathrm{~b}$ \\
\hline
\end{tabular}

${ }^{A}$ Dicamba, glufosinate, and glyphosate were applied at 599, 594, and $1543 \mathrm{~g}$ ai ha ${ }^{-1}$. All treatments included a water conditioning agent/nonionic surfactant blend at $1 \% v / v$ (Class Act ${ }^{\circledR}$ Ridion ${ }^{\circledR}$, Winfield Solutions, LLC, St. Paul, MN 55164, USA). ${ }^{\mathrm{B}}$ Means within a column followed by the same letter do not differ significantly at $p=0.05$ based on Tukey's HSD. C Visual injury estimated on a scale of $0 \%$ (no injury) to $100 \%$ (complete mortality). ${ }^{D}$ No treatment by year interaction observed for Palmer amaranth control 14 DAIT; therefore data were combined across years to show treatment effects. ${ }^{\mathrm{E}}$ A treatment by year interaction was observed for Palmer amaranth control 28 DAIT at $p=0.05$; therefore, data were analyzed and presented separately for each year. ${ }^{\mathrm{F}}$ Abbreviation: DAIT, days after initial treatment.

Palmer amaranth control of these dicamba based programs ranged from 79 to $94 \%$. Glufosinate applied $7 \mathrm{~d}$ before dicamba + glyphosate resulted in the lowest Palmer amaranth control 14 DAIT at $77 \%$. Sequential applications of dicamba + glyphosate fb glufosinate provided at least $87 \%$ control 14 DAIT regardless of the time interval tested. Treatments of dicamba + glyphosate fb glufosinate 7 DAIT resulted in complete mortality by 28 DAIT whereas the reverse sequence resulted in $70 \%$ control in 2018 . However, control at 28 DAIT was variable among years and all dicamba based programs performed similarly in 2019. Programs of glufosinate fb glufosinate or glufosinate fb dicamba + glyphosate 7 DAIT did not adequately control Palmer amaranth 28 DAIT in either year with ratings of 78 and $57 \%$ in 2018 and 2019, respectively. Dicamba + glyphosate fb either glufosinate 3 DAIT or dicamba + glyphosate again 7 DAIT produced better Palmer control (32 and 34\% respectively) than glufosinate fb glufosinate treatment at 28 DAIT in 2019. Randell et al. [31] observed less than $90 \%$ Palmer amaranth control with sequential glufosinate applications at $660 \mathrm{~g}$ ai ha ${ }^{-1}$ spaced 10 to $14 \mathrm{~d}$ apart which resulted in 20,000 to 27,000 survivors $\mathrm{ha}^{-1}$. These data suggest addition of auxin herbicide should be considered in dicamba and 2,4-D tolerant crops to reduce the number of Palmer amaranth escapes and increase control efficacy on large Palmer amaranth as glufosinate alone can be unreliable when targeting larger weeds.

All dicamba programs resulted in significantly reduced Palmer amaranth height as compared to the nontreated control in 2018 and 2019 (Table 5). All herbicide treatments resulted in plants at least $106 \mathrm{~cm}$ shorter than those in the nontreated control in 2018, with applications of dicamba + glyphosate $\mathrm{fb}$ glufosinate 7 DAIT resulting in complete mortality and no plant height could be measured. The greatest height reductions in 2019 were recorded in plots treated with dicamba + glyphosate fb glufosinate 3 DAIT and dicamba + glyphosate fb dicamba + glyphosate 7 DAIT, which were 100 and $101 \mathrm{~cm}$ lower than nontreated control respectively. Biomass reductions produced by dicamba + glyphosate $\mathrm{fb}$ glufosinate 7 DAIT did not differ significantly from the other treatments, although total control was observed with this treatment in 2018. All other treatments reduced biomass by at least 10,000 $\mathrm{kg} \mathrm{ha}^{-1}$ relative to nontreated control in 2018. With exception of glufosinate fb dicamba + glyphosate 7 DAIT, all treatments were lower than $1000 \mathrm{~kg} \mathrm{ha}^{-1}$. The same level of performance was not observed in 2019 and all treatments produced statistically similar amount of biomass ranged from 3265 to $5920 \mathrm{~kg} \mathrm{ha}^{-1}$. Sequential applications where dicamba + glyphosate was applied before glufosinate resulted in Palmer amaranth biomass of 0 to 403 and 3784 to $5920 \mathrm{~kg} \mathrm{ha}^{-1}$ in 2018 and 2019, respectively, which were not significantly better than glufosinate sprayed twice or glufosinate fb dicamba + glyphosate. Vann et al. [21] demonstrated that salvage programs can be effective in Xtendflex $\operatorname{cotton}^{\mathrm{TM}}$ (Monsanto Co, St. Louis, MO 63167) with sequential applications of dicamba + glufosinate combined with a layby application of diuron + MSMA which provided 94 to $99 \%$ control of Palmer amaranth, ranging in heights of 7 to $71 \mathrm{~cm}$ tall at the initial application. However, current labels do not allow dicamba and 
glufosinate tank mixtures and sequential applications will be the only option to utilize both herbicides in dicamba tolerant crops. These data suggest that dicamba applied before glufosinate may be more effective to control large Palmer amaranth than the reverse sequence. However, glufosinate $\mathrm{fb}$ dicamba programs and glufosinate fb glufosinate can still be considered viable options if weather conditions do not permit dicamba to be applied first, or in situation where Palmer amaranth size is smaller. Based on data generated from this study, consistent control of large Palmer amaranth is not guaranteed in either dicamba or 2,4-D resistant crops in rescue situations, and herbicide efficacy in rescue situations is subject to plant height and abiotic influences, thus may vary each year.

Table 5. Palmer amaranth height and biomass as affected by sequential applications of dicamba and glufosinate in 2018 and 2019 field studies.

\begin{tabular}{|c|c|c|c|c|c|c|c|c|c|c|}
\hline \multicolumn{3}{|c|}{ Treatments A,B } & \multicolumn{4}{|c|}{ Height $(\mathrm{cm})$ C,D } & \multicolumn{4}{|c|}{ Biomass (kg ha-1) } \\
\hline $\begin{array}{l}\text { Dicamba + } \\
\text { glyphosate }\end{array}$ & glufosinate & 7 & 0 & $\mathrm{~d}$ & 40 & $\mathrm{bc}$ & 0 & $\mathrm{~b}$ & 5920 & $\mathrm{ab}$ \\
\hline Glufosinate & dicamba + glyphosate & 7 & 24 & $\mathrm{bc}$ & 51 & $\mathrm{~b}$ & 3305 & $\mathrm{~b}$ & 3265 & $\mathrm{~b}$ \\
\hline Glufosinate & glufosinate & 7 & 21 & $\mathrm{bc}$ & 52 & $\mathrm{~b}$ & 903 & $\mathrm{~b}$ & 3387 & $\mathrm{~b}$ \\
\hline Nontreated control & - & - & 133 & $\mathrm{a}$ & 135 & $\mathrm{a}$ & 13,569 & $\mathrm{a}$ & 10,175 & $\mathrm{a}$ \\
\hline $\begin{array}{l}\text { A Dicamba, gluf } \\
\text { water condition } \\
\text { Paul, MN 55164, } \\
\text { within a column } \\
\text { by treatment int } \\
\text { analyzed and pr }\end{array}$ & $\begin{array}{l}\text { inate, and glyphosate } \\
\text { agent/nonionic surfa } \\
\text { SSA). }{ }^{B} \text { Palmer amarar } \\
\text { llowed by the same le } \\
\text { action was observed fo } \\
\text { ented separately for ea }\end{array}$ & $\begin{array}{l}\text { vere applied at } 5 \\
\text { tant blend at } 1 \% \\
\text { h height and abc } \\
\text { er do not differ s } \\
\text { Palmer amaran } \\
\text { h year. }{ }^{E} \text { Abbrev }\end{array}$ & $\begin{array}{l}594, \\
\text { (Cla } \\
\text {-grot } \\
\text { fican } \\
\text { eigh }\end{array}$ & $\begin{array}{l}\text { Act } \\
\text { Ares } \\
\text { at } p \\
\text { id b }\end{array}$ & $\begin{array}{l}\text { Ridic } \\
\text { bion } \\
0.05\end{array}$ & ss $\mathrm{r}$ & $\begin{array}{l}\text { All trea } \\
\text { nfield } \\
\text { corded } \\
\text { on Tuke } \\
0.05 \text {; th }\end{array}$ & DA & $\begin{array}{l}\text { nclude } \\
\text { s, LLC, } \\
\text { C Mea } \\
\text { D A y } \\
\text { data w }\end{array}$ & \\
\hline
\end{tabular}

Although new technology is available allowing broadcast applications of synthetic auxins and glufosinate in cotton and soybeans during the growing season, Palmer amaranth control can be variable among years and locations $[19,24]$. Herbicide efficacy can be significantly impacted by Palmer amaranth size, maturity, and growing conditions [23,32-34]. Height and biomass of Palmer amaranth in this study was similar in nontreated control plots among years with heights averaging from 133 and $135 \mathrm{~cm}$ and biomass of 13,569 and 10,175 $\mathrm{kg} \mathrm{ha}^{-1}$ at maturity in 2018 and 2019, respectively. However, herbicide performance was highly variable between years as Palmer amaranth heights at initial application ranged from 0 to 39 and 34 to $52 \mathrm{~cm}$ for all treatments in 2018 and 2019, respectively. These observations suggest plants received adequate time to reach maturity before collecting height and biomass data. Palmer amaranth height at initial applications was likely the greatest factor to influence the level of control observed. Palmer amaranth heights at initial applications had a greater impact on efficacy of dicamba-based programs than 2,4-D choline-based programs. In 2019, adverse weather conditions (rainy and windy days) prior to initial herbicide applications resulted in a substantial delay (8 days late) and allowed for additional Palmer amaranth growth. This occurrence is a frequent challenge for producers and plants can quickly exceed optimal heights for control with growth rates reported up to $5 \mathrm{~cm}$ per day $[7,8]$.

Taller, more mature plants with a larger canopy can reduce herbicide coverage of lower leaves, potentially impacting glufosinate efficacy. Glufosinate is a contact herbicide which requires adequate coverage and absorption to be effective [35]. For these reasons, glufosinate applications are only recommended for plants smaller than $7.5 \mathrm{~cm}$ tall are not as effective on larger Palmer amaranth [27,36-38]. Similarly, Cuvaca et al. [33] observed 7\% reductions in dicamba absorption and $15 \%$ lower translocation in Palmer amaranth $30 \mathrm{~cm}$ tall as compared to $10 \mathrm{~cm}$ tall. Dicamba and 2,4-D are systemic herbicides and efficacy is dependent on translocation within the plant [35]. Larger plants may have thicker plant cuticles which could reduce herbicide penetration resulting in poor control $[27,36,39]$. Furthermore, mature plants have reduced sugar transport which may decrease translocation of some systemic 
herbicides $[34,40,41]$. Highest label rate of glufosinate $\left(880 \mathrm{~g}\right.$ ai ha $\left.{ }^{-1}\right)$ plus ammonium sulfate and application under optimal environmental conditions may be required to provide additional control of large Palmer amaranth plants [42,43].

\subsection{Greenhouse Study}

Glufosinate applications severely inhibited Palmer amaranth mid-day photosynthesis as compared to dicamba. Treatments in which glufosinate was applied initially reduced mid-day photosynthesis at least $90 \% 1$ DAIT whereas dicamba applied initially only reduced photosynthesis $22 \%$ (Table 6). Photosynthetic rates improved over time and were not significantly different from the nontreated control by 8 DAIT. Dicamba + glyphosate fb glufosinate reduced photosynthesis by $84 \%$ compared to nontreated control 8 DAIT whereas glufosinate fb dicamba + glyphosate was similar to the nontreated control at that timing. No treatment differences in photosynthetic rates were observed 13 DAIT or in regenerated tissue 35 DAIT. Quantum yield of PSII followed similar trends as mid-day photosynthesis with the greatest immediate reductions observed for glufosinate applications, whether applied before, after, or tank mixed with dicamba + glyphosate. No statistical differences were observed for quantum yield of PSII for any treatment at and after 13 DAIT, suggesting PSII has returned to normal function. Similar to the mid-day photosynthesis measurements, the only treatment that resulted in reduced PSII quantum yield 11 DAIT was dicamba + glyphosate fb glufosinate 7 DAIT, potentially indicating slower Palmer amaranth recovery from this treatment.

Leaf stomatal conductance and photosynthesis were variable in the nontreated control at different measurement timings, likely impacted by daily changes in temperature and humidity (Table 6).

Treated Palmer amaranth did not result in reduced stomatal conductance relative to the nontreated control with exception of 1 DAIT where reductions of $67 \%, 46 \%$, and $89 \%$ were observed for three-way mix, dicamba + glyphosate fb glufosinate, and glufosinate fb dicamba + glyphosate treatments, respectively. Similar to mid-day photosynthetic observations 1 DAIT, treatments with glufosinate applied first inhibited stomatal conductance at a greater magnitude as compared to dicamba + glyphosate applied first. Respiration measurements were likely confounded by tissue degradation resulted from glufosinate applications. Glufosinate is a contact herbicide that causes rapid defoliation which may have resulted in an excess of carbon dioxide release as opposed to carbon dioxide flux due to respiration [35]. This would explain the more negative respiration values observed 1 DAIT from glufosinate treatments as opposed to dicamba which is a synthetic auxin and does not induce rapid defoliation. Ammonium accumulation and stomatal closure have been suggested to cause rapid photosynthetic inhibition in Palmer amaranth treated with glufosinate in as little as $30 \mathrm{~min}$ after application [44]. However, the results of this study suggest stomatal conductance was not severely impacted by dicamba + glyphosate and glufosinate applied sequentially or in tank mixtures. The possibility exists that the combination of two herbicides with distinctly different modes of action may have interfered with transpiration processes.

Regrowth of Palmer amaranth is often a major concern associated with glufosinate applications as glufosinate does not prevent weed regrowth [26,27]. All treatments in this study resulted in similar and significantly lower leaf biomass and area 14 DAIT as compared to the nontreated control (Table 7). 
Table 6. Physiological measurements following herbicide applications in greenhouse.

\begin{tabular}{|c|c|c|c|c|c|c|c|c|c|c|c|c|c|c|}
\hline \multirow[b]{2}{*}{ Treatment $\mathrm{A}, \mathrm{B}, \mathrm{C}, \mathrm{D}$} & \multicolumn{14}{|c|}{ Measurement Timings (DAIT) $^{\mathrm{E}}$} \\
\hline & \multicolumn{2}{|c|}{1} & \multicolumn{2}{|c|}{3} & \multicolumn{2}{|c|}{6} & \multicolumn{2}{|c|}{8} & \multicolumn{2}{|c|}{11} & \multicolumn{2}{|c|}{13} & \multicolumn{2}{|c|}{35} \\
\hline \multicolumn{15}{|l|}{ Mid-day photosynthesis $\left(\mu \mathrm{mol} \mathrm{CO}_{2} \mathrm{~m}^{-2} \mathrm{~s}^{-1}\right.$ ) } \\
\hline Dicamba + glufosinate +glyphosate & 1.84 & $c$ & 8.92 & c & 9.18 & $\mathrm{c}$ & 20.23 & a & 27.38 & $\mathrm{ab}$ & 30.94 & a & 24.54 & $\mathrm{a}$ \\
\hline Dicamba + glyphosate fb glufosinate 7 DAIT & 29.31 & $\mathrm{~b}$ & 36.02 & $\mathrm{ab}$ & 25.33 & $a b$ & 4.16 & $\mathrm{~b}$ & 11.92 & $\mathrm{c}$ & 31.36 & a & 23.29 & $\mathrm{a}$ \\
\hline Glufosinate fb dicamba + glyphosate 7 DAIT & 3.76 & $c$ & 18.62 & bc & 13.21 & $\mathrm{bc}$ & 11.33 & $\mathrm{ab}$ & 21.59 & $\mathrm{bc}$ & 27.29 & a & 21.07 & a \\
\hline Nontreated control & 37.70 & a & 44.58 & a & 33.57 & $\mathrm{a}$ & 26.09 & $\mathrm{a}$ & 36.48 & a & 27.14 & a & 23.39 & a \\
\hline \multicolumn{15}{|l|}{ Stomatal conductance $\left(\mathrm{mmol} \mathrm{H}_{2} \mathrm{O} \mathrm{m}^{-2} \mathrm{~s}^{-1}\right)$} \\
\hline Dicamba + glufosinate +glyphosate & 0.16 & $\mathrm{bc}$ & 0.14 & a & 0.38 & a & 0.27 & a & 0.29 & a & 0.26 & a & 0.16 & a \\
\hline Glufosinate fb dicamba + glyphosate 7 DAIT & 0.05 & c & 0.19 & a & 0.16 & $\mathrm{ab}$ & 0.13 & a & 0.18 & $\mathrm{a}$ & 0.19 & a & 0.13 & $\mathrm{a}$ \\
\hline Nontreated control & 0.47 & a & 0.29 & a & 0.26 & $\mathrm{~b}$ & 0.21 & a & 0.30 & $\mathrm{a}$ & 0.18 & a & 0.17 & $\mathrm{a}$ \\
\hline \multicolumn{15}{|l|}{ Respiration $\left(\mu \mathrm{mol} \mathrm{CO}_{2} \mathrm{~m}^{-2} \mathrm{~s}^{-1}\right)$} \\
\hline Dicamba + glufosinate + glyphosate & -2.66 & c & -3.21 & $\mathrm{~b}$ & -3.68 & $\mathrm{~b}$ & -1.50 & $\mathrm{ab}$ & -1.41 & $\mathrm{a}$ & -1.49 & $\mathrm{~b}$ & - & - \\
\hline Dicamba + glyphosate fb glufosinate 7 DAIT & -1.24 & $\mathrm{a}$ & -1.70 & a & -1.76 & $\mathrm{a}$ & -1.68 & $\mathrm{ab}$ & -1.34 & $\mathrm{a}$ & -1.34 & $\mathrm{~b}$ & - & - \\
\hline Glufosinate fb dicamba + glyphosate 7 DAIT & -2.34 & $\mathrm{bc}$ & -2.30 & $\mathrm{ab}$ & -1.91 & $\mathrm{a}$ & -2.11 & $\mathrm{~b}$ & -1.67 & $\mathrm{a}$ & -0.72 & a & - & - \\
\hline Nontreated control & -2.00 & $\mathrm{~b}$ & -1.99 & a & -1.99 & $\mathrm{a}$ & -1.23 & a & -1.42 & a & -0.98 & $\mathrm{ab}$ & - & - \\
\hline \multicolumn{15}{|l|}{ PSII Quantum Yield } \\
\hline Dicamba + glufosinate +glyphosate & 0.41 & $\mathrm{~b}$ & 0.63 & $\mathrm{~b}$ & 0.64 & $a b$ & 0.63 & $a b$ & 0.77 & a & 0.77 & a & - & - \\
\hline Nontreated control & 0.77 & $\mathrm{a}$ & 0.76 & $\mathrm{a}$ & 0.79 & $\mathrm{a}$ & 0.79 & $\mathrm{a}$ & 0.77 & $\mathrm{a}$ & 0.77 & $\mathrm{a}$ & - & - \\
\hline
\end{tabular}

${ }^{\mathrm{A}}$ Abbreviation: DAIT, days after initial treatment, PSII, photosystem II. ${ }^{\mathrm{B}}$ Photosynthesis and leaf stomatal conductance measurements were recorded at solar noon while respiration and PSII quantum yield measurements were recorded from dark-adapted plants. ${ }^{\mathrm{C}}$ A treatment by measurement timing was observed for photosynthetic assimilation, leaf stomatal conductance, foliar dark respiration, and PSII quantum yield at $p=0.05$; therefore, data were analyzed separately for each measurement timing. ${ }^{\mathrm{D}}$ Dicamba, glufosinate, and glyphosate were applied at 186, 198, $514 \mathrm{~g}$ ai ha ${ }^{-1}$. ${ }^{\mathrm{E}}$ Means for each type of measurement within a column followed by the same letter do not differ significantly at $p=0.05$ based on Tukey's HSD. 
Table 7. Palmer amaranth leaf area index and biomass as affected by herbicide treatments in greenhouse.

\begin{tabular}{ccccccc}
\hline \multirow{2}{*}{ Treatment A,B,C,D } & \multirow{2}{*}{ Leaf Area $\mathbf{( c m}^{\mathbf{2}}$ ) } & \multicolumn{3}{c}{ Fresh Leaf Biomass (g) } \\
\cline { 5 - 7 } & & & 14 DAIT & & 35 DAIT \\
\hline Dicamba + glufosinate +glyphosate & 157.70 & $\mathrm{~b}$ & 6.50 & $\mathrm{~b}$ & 12.42 & $\mathrm{a}$ \\
Dicamba + glyphosate fb glufosinate 7 DAIT & 228.09 & $\mathrm{~b}$ & 8.91 & $\mathrm{~b}$ & 6.12 & $\mathrm{~b}$ \\
Glufosinate fb dicamba + glyphosate 7 DAIT & 192.78 & $\mathrm{~b}$ & 7.43 & $\mathrm{~b}$ & 9.68 & $\mathrm{ab}$ \\
Nontreated control & 569.66 & $\mathrm{a}$ & 14.96 & $\mathrm{~b}$ & 11.68 & $\mathrm{a}$ \\
\hline
\end{tabular}

A Abbreviation: DAIT, days after initial treatment. ${ }^{\text {B }}$ Dicamba, glufosinate, and glyphosate were applied at 186, 198, $514 \mathrm{~g}$ a $\mathrm{ha}^{-1}$. C Leaf area and biomass data collected 14 DAIT, then Palmer amaranth stems with no leaves were allowed to regrow until 35 DAIT when leaf biomass was collected for the second time. ${ }^{\mathrm{D}}$ Means within a column followed by the same letter do not differ significantly at $p=0.05$ based on Tukey's HSD.

When plants were allowed to continue growth over a three-week period following leaf removal 14 DAIT, the only treatment that resulted in significantly lower leaf biomass from growth was dicamba + glyphosate fb glufosinate 7 DAIT. These data suggest Palmer amaranth recovery may be impaired by application of dicamba + glyphosate fb glufosinate as compared to the reverse sequence or tank mixture, which has valuable implication for Palmer amaranth management in field. Coetzer et al. [45] showed that less than $2 \%$ of glufosinate is translocated outside of the leaf where it was applied. This observation illustrates the need for adequate coverage when applying glufosinate to larger plants with sizable canopy. Such a scenario may explain the lack of control 28 DAIT observed in the field for sequential glufosinate applications by itself, where rapid defoliation occurred but glufosinate was unable to kill large Palmer stem due to lack of coverage, thus allowing plant to regrow and recover from injury.

\section{Discussion}

Incorporation of multiple modes of action into weed control programs is frequently recommended by weed scientists to reduce Palmer amaranth survivors and delay evolution of herbicide resistance $[8,46]$. Results of this study suggest multiple applications of POST herbicides with different modes of action may increase control of large Palmer amaranth. Sequential applications of synthetic auxins fb glufosinate are more likely to rescue Palmer amaranth infested fields as opposed to the reverse sequence. Glufosinate alone applied sequentially did not adequately control large Palmer amaranth in either year of this study. Higher rate of glufosinate plus ammonium sulfate may be needed to enhance control efficacy when 2,4-D or dicamba cannot be utilized due to spray drift concern. Although some combinations of sequential applications of synthetic auxins and glufosinate were effective, herbicide applications to large Palmer amaranth $(>10 \mathrm{~cm})$ is not recommended and timely applications of POST herbicides remain the most effective approach. Although results found in this study indicate sequential applications of 2,4-D, dicamba and glufosinate may have potential to rescue infested fields, Palmer amaranth control was not consistent among years with different growing conditions, suggesting rescue practice should be avoided if possible. If salvage programs are utilized and fail, manual removal is required to limit seed return to the soil seed bank and reduce the risks of herbicide resistance development.

\section{Conclusions}

Field study confirmed that 2,4-D or dicamba sprayed in sequence with glufosinate provided better Palmer amaranth control than single application and two applications of glufosinate alone, regardless 3- or 7-days interval between applications. Palmer amaranth size at application plays a key role to achieving sufficient control. No treatment provided complete control of large Palmer $(>30 \mathrm{~cm})$ which indicated the importance of spraying timely. Data from greenhouse study glufosinate immediately reduced up to $90 \%$ mid-day photosynthesis in terms of $\mathrm{CO}_{2}$ assimilation within $24 \mathrm{hrs}$. Palmer amaranth respiration and stomatal conductance were not affected by herbicides in this study. Dicamba 
+ glyphosate fb glufosinate 7 DAIT was the only treatment reduced Palmer amaranth regrowth as compared to non-treated check. Results of this study suggested salvage treatment using auxin herbicide and glufosinate should be applied in sequence to be effective on large Palmer and should be only used when necessary due to variable efficacy observed in this study. Timely application to smaller weed $(<10 \mathrm{~cm})$ needs to be adhered to prevent large Palmer escapes in the first place as this weed grows rapidly under optimum conditions.

Author Contributions: Conceptualization, X.L. and F.B.B.; methodology, X.L., F.B.B., A.S.-S.d.J.; software, F.B.B.; validation, F.B.B.; formal analysis, F.B.B.; investigation, F.B.B., K.J.P., R.L., A.S.-S.d.J.; resources, K.J.P., A.S.-S.d.J.; data curation, F.B.B.; writing-original draft preparation, F.B.B.; writing-review and editing, F.B.B., J.S.M., A.P., K.J.P., Y.F.; supervision, X.L., K.J.P.; project administration, X.L.; funding acquisition, X.L. All authors have read and agreed to the published version of the manuscript.

Funding: This research was funded by Alabama Cotton Commission.

Acknowledgments: The authors of this paper would like to thank Alabama Cotton Commission for funding this study and Alabama Agricultural Experiment Station for managing field trials.

Conflicts of Interest: The authors declare no conflict of interest.

\section{References}

1. Korres, N.E.; Norsworthy, J.K.; Mauromoustakos, A. Effects of Palmer Amaranth (Amaranthus palmeri) Establishment Time and Distance from the Crop Row on Biological and Phenological Characteristics of the Weed: Implications on Soybean Yield. Weed Sci. 2019, 67, 126-135. [CrossRef]

2. Franssen, A.S.; Skinner, D.Z.; Al-Khatib, K.; Horak, M.J.; Kulakow, P.A. Interspecific hybridization and gene flow of ALS resistance in Amaranthus species. Weed Sci. 2011, 49, 598-606. [CrossRef]

3. Ward, S.M.; Webster, T.M.; Steckel, L.E. Palmer Amaranth (Amaranthus palmeri): A Review. Weed Technol. 2013, 27, 12-27. [CrossRef]

4. Smith, D.T.; Baker, R.V.; Steele, G.L. Palmer amaranth (Amaranthus palmeri) impacts on yield, harvesting, and ginning in dryland cotton (Gossypium hirsutum). Weed Technol. 2000, 14, 122-126. [CrossRef]

5. MacRae, A.W.; Culpepper, A.S.; Webster, T.M.; Sosnoskie, L.M.; Kichler, J.M. Glyphosate-resistant Palmer amaranth competition with Roundup Ready ${ }^{\circledR}$ cotton. In Beltwide Cotton Conf.; National Cotton Council: Nashville, TN, USA, 2008; pp. 8-11.

6. Morgan, G.D.; Baumann, P.A.; Chandler, J.M. Weed Science Society of America Competitive Impact of Palmer Amaranth (Amaranthus palmeri) on Cotton (Gossypium hirsutum) Development and Yield1. Weed Technol. 2001, 15, 408-412. [CrossRef]

7. Horak, M.J.; Loughin, T.M. Growth analysis of fourAmaranthusspecies. Weed Sci. 2000, 48, 347-355. [CrossRef]

8. Culpepper, A.S.; Webster, T.M.; Sosnoskie, L.M.; York, A.C.; Nandula, V.K. Glyphosate-resistant Palmer amaranth in the United States. In Glyphosate Resistance in Crops and Weeds: History, Development, and Management; John Wiley \& Sons: Hoboken, NJ, USA, 2010; pp. 195-212.

9. Sellers, B.A.; Smeda, R.J.; Johnson, W.G.; Kendig, J.A.; Ellersieck, M.R. Comparative growth of six Amaranthus species in Missouri. Weed Sci. 2003, 51, 329-333. [CrossRef]

10. Klingaman, T.E.; Oliver, L.R. Palmer amaranth (Amaranthus palmeri) interference in soybeans (Glycine max). Weed Sci. 1994, 42, 523-527. [CrossRef]

11. Rowland, M.W.; Murray, D.S.; Verhalen, L.M. Full-season Palmer amaranth (Amaranthus palmeri) interference with cotton (Gossypium hirsutum). Weed Sci. 1999, 47, 305-309. [CrossRef]

12. Bensch, C.N.; Horak, M.J.; Peterson, D. Interference of redroot pigweed (Amaranthus retroflexus), Palmer amaranth (A. palmeri), and common waterhemp (A. rudis) in soybean. Weed Sci. 2003, 51, 37-43. [CrossRef]

13. Norsworthy, J.K.; Griffith, G.; Griffin, T.; Bagavathiannan, M.; Gbur, E.E. In-Field Movement of Glyphosate-Resistant Palmer Amaranth (Amaranthus palmeri) and Its Impact on Cotton Lint Yield: Evidence Supporting a Zero-Threshold Strategy. Weed Sci. 2014, 62, 237-249. [CrossRef]

14. Keeley, P.E.; Carter, C.H.; Thullen, R.J. Influence of Planting Date on Growth of Palmer Amaranth (Amaranthus palmeri). Weed Sci. 1987, 35, 199-204. [CrossRef] 
15. Heap, I. The International Survey of Herbicide Resistant Weeds. 2019. Available online: www.weedscience. org (accessed on 14 February 2020).

16. Anonymous. Liberty ${ }^{\circledR} 280$ SL Herbicide Label. Bayer CropScience, Research Triangle Park, North Carolina. 2016. Available online: http://www.cdms.net/ldat/ldUA5013.pdf (accessed on 14 February 2020).

17. Tehranchian, P.; Norsworthy, J.K.; Powles, S.B.; Bararpour, M.T.; Bagavathiannan, M.V.; Barber, T.; Scott, R.C. Recurrent Sublethal-Dose Selection for Reduced Susceptibility of Palmer Amaranth (Amaranthus palmeri) to Dicamba. Weed Sci. 2017, 65, 206-212. [CrossRef]

18. Inman, M.D.; Jordan, D.; York, A.C.; Jennings, K.M.; Monks, D.W.; Everman, W.J.; Bollman, S.L.; Fowler, J.T.; Cole, R.M.; Soteres, J.K. Long-Term Management of Palmer Amaranth (Amaranthus palmeri) in Dicamba-Tolerant Cotton. Weed Sci. 2016, 64, 161-169. [CrossRef]

19. Merchant, R.M.; Culpepper, A.S.; Eure, P.M.; Richburg, J.S.; Braxton, L.B. Salvage Palmer Amaranth Programs Can Be Effective in Cotton Resistant to Glyphosate, 2,4-D, and Glufosinate. Weed Technol. 2014, 28, 316-322. [CrossRef]

20. Lawrence, B.H.; Bond, J.A.; Eubank, T.W.; Golden, B.R.; Cook, D.R.; Mangialardi, J.P. Evaluation of 2,4-D-based Herbicide Mixtures for Control of Glyphosate-Resistant Palmer Amaranth (Amaranthus palmeri). Weed Technol. 2018, 33, 263-271. [CrossRef]

21. Vann, R.A.; York, A.C.; Cahoon, C.W.; Buck, T.B.; Askew, M.C.; Seagroves, R.W. Effect of delayed dicamba plus glufosinate application on Palmer amaranth (Amaranthus palmeri) control and Xtendflex ${ }^{\mathrm{TM}}$ cotton yield. Weed Technol. 2017, 31, 633-640. [CrossRef]

22. Barnett, K.A.; Culpepper, A.S.; York, A.C.; Steckel, L.E. Palmer Amaranth (Amaranthus palmeri) Control by Glufosinate plus Fluometuron Applied Postemergence to WideStrike ${ }^{\circledR}$ Cotton. Weed Technol. 2013, 27, 291-297. [CrossRef]

23. Corbett, J.L.; Askew, S.D.; Thomas, W.E.; Wilcut, J.W. Weed Efficacy Evaluations for Bromoxynil, Glufosinate, Glyphosate, Pyrithiobac, and Sulfosate. Weed Technol. 2004, 18, 443-453. [CrossRef]

24. Merchant, R.M.; Sosnoskie, L.M.; Culpepper, A.S.; Steckel, L.E.; York, A.C.; Braxton, L.B.; Ford, J.C. Weed response to 2, 4-D, 2, 4-DB, and dicamba applied alone or with glufosinate. J. Cotton Sci. 2013, 17, 212-218.

25. Craigmyle, B.D.; Ellis, J.M.; Bradley, K. Influence of Weed Height and Glufosinate plus 2,4-D Combinations on Weed Control in Soybean with Resistance to 2,4-D. Weed Technol. 2013, 27, 271-280. [CrossRef]

26. Vann, R.A.; York, A.C.; Cahoon, C.W.; Buck, T.B.; Askew, M.C.; Seagroves, R.W. Glufosinate plus dicamba for rescue palmer amaranth control in XtendFlex TM cotton. Weed Technol. 2017, 31, 666-674. [CrossRef]

27. Coetzer, E.; Al-Khatib, K.; Peterson, D.E. Glufosinate Efficacy on Amaranthus Species in Glufosinate-Resistant Soybean (Glycine max)1. Weed Technol. 2002, 16, 326-331. [CrossRef]

28. Anonymous. Xtendimax®with VaporGrip®Technology Label; Monsanto Co.: St. Louis, MO, USA, 2018; Available online: http://www.cdms.net/ldat/ldDF9006.pdf (accessed on 14 February 2020).

29. Anonymous. Engenia®Herbicide Label; BASF Corporation: Triangle Park, NC, USA, 2018; Available online: http://www.cdms.net/ldat/ldDG8028.pdf (accessed on 14 February 2020).

30. Anonymous. Tavium®Plus VaporGrip®Technology Label; Syngenta Crop Protection, LLC: Greensboro, NC, USA, 2019; Available online: http://www.cdms.net/ldat/ldFSO000.pdf (accessed on 18 March 2020).

31. Randell, T.M.; Hand, L.C.; Vance, J.C.; Culpepper, A.S. Interval between sequential glufosinate applications influences weed control in cotton. Weed Technol. 2020, 34, 528-533. [CrossRef]

32. Walker, E.R.; Oliver, L.R. Weed Seed Production as Influenced by Glyphosate Applications at Flowering Across a Weed Complex. Weed Technol. 2008, 22, 318-325. [CrossRef]

33. Meyer, C.J.; Norsworthy, J.K. Influence of weed size on herbicide interactions for Enlist ${ }^{\mathrm{TM}}$ and Roundup Ready ${ }^{\circledR}$ Xtend ${ }^{\circledR}$ technologies. Weed Technol. 2019, 33, 569-577. [CrossRef]

34. Cuvaca, I.; Currie, R.; Roozeboom, K.; Fry, J.; Jugulam, M. Increased Absorption and Translocation Contribute to Improved Efficacy of Dicamba to Control Early Growth Stage Palmer amaranth (Amaranthus palmeri). Weed Sci. 2019, 68, 1-25. [CrossRef]

35. Shaner, D.L. Herbicide Handbook of the Weed Science Society of America; Weed Science Society of America: Champaign, IL, USA, 2014; pp. 22-232.

36. ArrayExpress-A Database of Functional Genomics Experiments. Available online: http://www.ebi.ac.uk/ arrayexpress/ (accessed on 12 November 2012). 
37. York, A.C. Weed management in cotton. In 2017 Cotton Information; North Carolina Cooperative Extension Service Publ. AG-417: Raleigh, NC, USA, 2017; pp. 66-112. Available online: https://content.ces.ncsu.edu/ cotton-information/weed-management-in-cotton (accessed on 2 February 2020).

38. Everman, W.J.; Burke, I.C.; Allen, J.R.; Collins, J.; Wilcut, J.W. Weed Control and Yield with Glufosinate-Resistant Cotton Weed Management Systems. Weed Technol. 2007, 21, 695-701. [CrossRef]

39. Oosterhuis, D.M.; Hampton, R.E.; Wullschleger, S.D. Water deficits effects on the cotton leaf cuticle and the efficacy of defoliants. J. Prod. Agric. 1991, 4, 260-265. [CrossRef]

40. Kirkwood, R. Recent developments in our understanding of the plant cuticle as a barrier to the foliar uptake of pesticides. Pest Manag. Sci. 1999, 55, 69-77. [CrossRef]

41. Lemoine, R.; La Camera, S.; Atanassova, R.; Dédaldéchamp, F.; Allario, T.; Pourtau, N.; Bonnemain, J.-L.; Laloi, M.; Coutos-Thévenot, P.; Maurousset, L.; et al. Source-to-sink transport of sugar and regulation by environmental factors. Front. Plant Sci. 2013, 4. [CrossRef]

42. Maschhoff, J.R.; Hart, S.E.; Baldwin, J.L. Effect of ammonium sulfate on the efficacy, absorption, and translocation of glufosinate. Weed Sci. 2000, 48, 2-6. [CrossRef]

43. Pratt, D.; Kells, J.J.; Penner, D. Substitutes for Ammonium Sulfate as Additives with Glyphosate and Glufosinate1. Weed Technol. 2003, 17, 576-581. [CrossRef]

44. Coetzer, E.; Al-Khatib, K. Photosynthetic inhibition and ammonium accumulation in Palmer amaranth after glufosinate application. Weed Sci. 2001, 49, 454-459. [CrossRef]

45. Coetzer, E.; Al-Khatib, K.; Loughin, T.M. Glufosinate efficacy, absorption, and translocation in amaranth as affected by relative humidity and temperature. Weed Sci. 2001, 49, 8-13. [CrossRef]

46. Culpepper, A.S.; Vance, J.C. Palmer Amaranth Control in Georgia Cotton during 2019. University of Georgia Extension. Circular 952. June 2019. Available online: https:/extension.uga.edu/content/dam/extensioncounty-offices/irwin-county/anr/vol13.1-anr-newsletter-may2019.pdf (accessed on 18 March 2019).

(C) 2020 by the authors. Licensee MDPI, Basel, Switzerland. This article is an open access article distributed under the terms and conditions of the Creative Commons Attribution (CC BY) license (http://creativecommons.org/licenses/by/4.0/). 